\title{
LEARNING LOCAL WISDOM IN ELEMENTARY SCHOOL THROUGH MAJAPAHITAN STATUE
}

\author{
Putri Rachmadyanti ${ }^{1 *}$, Aristiya Nuraini ${ }^{2}$, Wiryanto ${ }^{3}$ \\ ${ }^{1,2,3}$ State University of Surabaya, East Java, Indonesia \\ Corresponding*putrirachmadyanti@unesa.ac.id; aristiya.18019@mhs.unesa.ac.id; \\ wiryanto@unesa.ac.id
}

DOI: https://doi.org/10.21107/Widyagogik/v8i1.8723

Received October 1, 2020; Revised October 3, 2020; Accepted October 31, 2020

\begin{abstract}
This study discusses one of the famous cultural products in East Java, namely the Majapahitan Statue from Mojokerto. The purpose of this study is to analyze the material contained in the Majapahitan Statue to support the development of local wisdom-based learning in Elementary Schools. The existence of The Mojopahitan Statue can be developed as a learning resource for thematic learning in accordance with the 2013 Curriculum to develop the competence of Elementary School Students comprehensively. The research using a qualitative approach with data collection techniques using interviews and observations. The values contained in the Majapahitan Statue were developed into a Learning Plan with a scientific approach. The Majapahitan statue contains the value of knowledge about history, natural resource, location. Affective aspects that can be obtained by students are learning about cooperation, discipline, and creativity. The psychomotor aspect includes skills in making reports about Majapahitan statues. Learning local wisdom is also a form of developing contextual learning that utilizes the environment as a source of student learning.
\end{abstract}

Keywords: local wisdom, elementary school, the majapahitan statue 
45 Learning Local Wisdom in Elementary School Through Majapahitan Statue

Putri Rachmadyanti, Aristiya Nuraini, Wiryanto

\section{Introduction}

Elementary School is an important level of education to develop the competence of knowledge, attitude, and skills of students, as a provision of students individually as well as in participating in the community environment. Elementary school students are at a stage of concrete operational cognitive development which means that students will easily obtain information. This is supported by the opinion of Piaget in the division of the stage of cognitive development, in his opinion students aged $7-11$ years have been able to think about something rational with concrete or tangible evidence. So that in the learning process in an elementary school directed to invite students in terms of remembering, thinking rationally, and being able to solve a problem involving a concrete object or something that can be seen by students themselves, it aims to make the student's learning experience and understanding included in social science learning.

Rusman (2017: 130) explains that the learning outcomes are essentially the abilities that students have after students have received the learning experience. Student learning outcomes can be cognitive, affective and psychomotor abilities. These abilities help students develop and adapt to the environment. This is in line with the opinion of the US-based Partnership for 21st Century Skills (P21) on 21st-century skills including critical thinking and Problem Solving (critical thinking and problem solving), creativity (creativity), communication skills (communication skills), and ability to work collaboratively (cooperation). Dream - this ability needs to be possessed in preparation for students as local, national, and global citizens. Related to this, local wisdom learning is one of the efforts that schools can make to develop all three aspects of the learning outcomes. Prawes Wasi (1993) explains thas education desirable in today's society will a study aimed at improving tha balance of the both cognitive, psychological, and social level, ideas, values, and behaviour, which must be consistent with the needs of individuals, communities, societies and nations.

Some studies have shown positive results in local wisdom-based learning. The research was analyzed puspita et al (2019) in PTK type research on improving creative writing skills in elementary school through local wisdom learning. The result was that in the first cycle $17 \%$ of students had a score $\leq 70$, and in the second cycle, there was an increase in be $76 \%$ of students who had a score $\leq 70$. Other research was conducted by Dwiyanti (2017) which is about the influence of local culture-based learning and the value of diversity on the learning outcomes of elementary school students in the Medan Johor sub-district. The results showed that the learning approach and diversity value influenced the students' IPS learning outcomes, there were differences in students' learning outcomes taught with a local culture-based approach with students' IPS learning outcomes taught with conventional approaches (Fhitung $=17,064$; sig $=0.000<$ 0.05).

In addition to students, the importance of understanding local wisdom is also necessary for teachers or prospective educators in elementary schools. A good understanding of the local wisdom that exists in the community to be used as learning material. The educational environment includes all material and stimuli inside and outside the individual, whether physiological, psychological, or socio-cultural (Soemanto in Ramdhani, 2014: 34). A teacher can be a competent and dignified generation, able to reflect cultural values, and participate in shaping the character of the nation. One of the local wisdom that can be used in social science learning materials is historical learning about the material identifying the relics of Hindu / Buddhist or Islamic kingdoms. And 
this time focusing on the Majapahit kingdom in Mojokerto, there is local wisdom in the form of majapahitan statue craft which is possible if used as a learning material both knowing the history, heritage, process of making statues and the influence of local wisdom in the surrounding community. It is called the majapahitan statue because it is an imitation of the original statue of the Majapahit kingdom. In the process of making majapahitan statues are always guided on the original objects of relics in the Majapahit kingdom. Majapahitan statue crafts not only produce about statues, but there are some other relics besides statues in production that are certainly still related to the relics of the Majapahit kingdom.

The reason for choosing the majapahitan statue study is because the Mojokerto area is famous for the historical heritage of the Majapahit Kingdom with Hindu and Buddhist pattern. The collapse of the Majapahit Kingdom leaves historical evidence of both land and water. From the historical heritage in Majapahit has a big influence in driving the economy in Mojokerto, especially in Bejijong Village, Trowulan Sub-District. The population in the region is $50 \%$ average- the average livelihood as a craftsman of majapahitan statues. Human activities in Bejijong Village are related to learning in elementary school in grade IV Theme 5 regarding the identification of Hindu/Buddhist or Islamic kingdoms in the local area and their influence on the lives of today's people.

To support the development of local wisdom learning in elementary school, the study of Majapahitan Statue was compiled as one of the materials that can be used to design learning. The focus of this study is to discuss the profile of the Majapahitan statue and the values contained in majapahitan statue crafts. After knowing the profile and also the values contained in Majapahitan Statue. Furthermore, these materials are used to develop comprehensive learning based on local wisdom.

\section{Method}

This study uses a type of qualitative research as revealed by Moleong (2012: 6) research procedure by understanding the phenomenon experienced by the research subject and then continuing to write down the data based on scientific methods. The subject of this research is the owner of one of the Statue Sculpting Businesses in Bejijong Village of Trowulan Sub-District, Mojokerto, namely Mr. Hari and his son named Muhammad Taufik Rochman.

The data retrieval technique is by conducting observations and interviews. Data analysis technique through 3 stages, namely reduction, presentation, and withdrawal of conclusions. The data reduction stage means dissing and choosing the main thing, focusing on the things that matter. The presentation of data is an activity when the information that has been obtained is compiled, for the material in the withdrawal of conclusions.

\section{Results and Discussions}

\section{A. Majapahitan Statue}

Local wisdom in Mojokerto city is one of the handicrafts of Majapahitan Statue, precisely in Trowulan Sub-District Mojokerto regency of East Java. There are many relics from the former Majapahit kingdom, so there is a lot of historical evidence of both land and water. The historical heritage of the Majapahit kingdom has a big 
47 Learning Local Wisdom in Elementary School Through Majapahitan Statue

Putri Rachmadyanti, Aristiya Nuraini, Wiryanto

influence in driving the economy in Mojokerto, especially in Bejijong Village, Trowulan Sub-District. This is evidenced by the data of the population in this area $50 \%$ average livelihood as a craftsman majapahitan statue and one of the residents who eyed the craftsman of the statue as well as the subject of a case study this time, namely Mr. Hari and his son named Muhammad Taufiq Rochman. Majapahitan statue crafts that Mr. Hari and his son have been through generations ranging from Mr. Hari's grandfather until now, he also has a shop to market his products both online and offline, the store is named HR. Artshop.

On Sunday, February 22, 2020, observation activities in Kedungwulan Village Bejijong Village RT.01 RW.02 Trowulan District mojokerto regency was conducted to dig up information about the history, manufacturing process, and influence of majapahitan statue crafts in the area. In the house occupied by Mr. Hari and his family, there are many types of Majapahitan statues either purely a relic of the Majapahit Kingdom or a self-made Majapahitan statue (imitation). Not only statues, but in the house, there are also stones, paintings, coins, plates, bowls, bricks, and other relics. These objects come from various places, some original Majapahit relics, made by Mr. Hari and his son, found around Trowulan and originated in various regions both in Indonesia and abroad. The house can be said to be a shop as well as a museum that holds many relics of the past precisely during the Majapahit period. The place is usually used by students or other people who want to just find out the historical information and process of making statues as well as those who want to learn to make statues.

In Mr. Hari's house, there are various types of statues, which are Hindu and Buddhist from both gods and other astral figures. The reason Mr. Hari pursued the first Majapahitan statue craft business was to reduce the unemployment rate in his area, Mr. Hari wanted to move his villagers to become creative and not idle people to produce money to meet the needs. Then the second reason Mr. Hari pursued while also establishing this shop is to preserve the culture that exists in Mojokerto. The area that Mr. Hari lived in is a culturally rich area of Majapahit kingdom many people from outside the city who are looking for relics from the great kingdom both for collection and for tools of worship. The next reason is the advantage of producing majapahitan statues is quite large, in this business Mr. Hari was able to send handicrafts in several cities such as Kediri, Malang, Madiun, Bali, Jogjakarta, and Solo. From the six cities, Solo became a regular customer of Mr. Hari. For delivery to Solo every month, Mr. Hari can achieve a fixed income of about $10-15$ million. In one production Mr. Hari can produce up to 2 - 3 quintal with a selling price of about $500,000-50,000,000$. In addition to being sold in his shop, Mr. Hari also sells handicrafts on one of the online store platforms named HR Artshop.

Similar to Mr. Hari's efforts, the people of Bejijong village also produce majapahitan statue crafts. And the marketing is also online as well as direct orders. The Bejijong village government was also noticed by providing cooperatives as a container for suppliers of artisans, but the cooperative did not guarantee the prosperity of its people because the cooperative was not always crowded with buyers and deposited the handicrafts of bejijong villagers. In the manufacture of the Majapahitan statue, there are manuals or design books to be created and some necessary tools and materials include: 
Table 1. Majapahitan Statue Making Tools and Materials

\begin{tabular}{|l|l|}
\hline \multicolumn{1}{|c|}{ Materials } & \multicolumn{1}{|c|}{ Tools } \\
\hline 1. Candle & 1. Stove \\
2. Cat eye shadow & 2. Statue prints \\
3. Water & 3. Sculptural knife \\
4. Cement & 4. Brush and soap \\
5. Brass & \\
6. Bronze & \\
7. Clay & \\
\hline
\end{tabular}

The process that is done to make the first Majapahitan statue is to print the basic form of the statue / make a print of the statue. This mold uses wax raw materials that were previously carved in advance based on the statue to be made. Then the wax that has been carved or formed is coated in cement mixed with water and silenced until it dries, after drying the wax that has been coated in the cement then boiled, in the process of boiling the wax will melt and cement will form a mold in the form of a statue to be made.

After the mold of cement is formed when the main process of making the statue is done, in the process of making the statue the first step done is by heating the wax on the stove. While waiting for the wax to melt, first clean the sculpted mold using a brush and soap to make it slippery so that the wax mold is easily detached. After the wax melts pour into the mold of the statue that has been cleaned. Just wait 5-10 seconds, then dip in the cold water that has been provided in the tub or bucket for a few seconds. Remove the print of the statue from the water and open the mold and the base shape of the statue has been finished. The basic shape of the statue made of wax will be coated in clay mixed with water to make a cast mold when the finished cast mold will then be filled with brass or bronze material through casting techniques. The time it takes to make a statue cannot be determined, depending on the complexity of the shape of the statue.

According to Mr. Hari the greater the profit earned then the greater the risk. Mr. Hari has experienced unfortunate events because he once got a consumer of Indonesian Toilets who are in Bali. The WNA brings away the goods of Father Hari without paying for it so that in this business needs thoroughness and prudence in everything from the manufacturing process and marketing to consumers. The payment method used by Mr. Hari is not direct, but rather through a check that can be paid a day to two days after the goods have been in the hands of consumers.Here is a table containing some majapahitan statues and other relics in HR. Artshop.

Table 2. Majapahitan Statue

\begin{tabular}{|l|c|c|}
\hline No & Picture & Name \\
\hline 1. & & Ganesha Statue \\
& Sof & \\
\hline
\end{tabular}


49 Learning Local Wisdom in Elementary School Through Majapahitan Statue

Putri Rachmadyanti, Aristiya Nuraini, Wiryanto

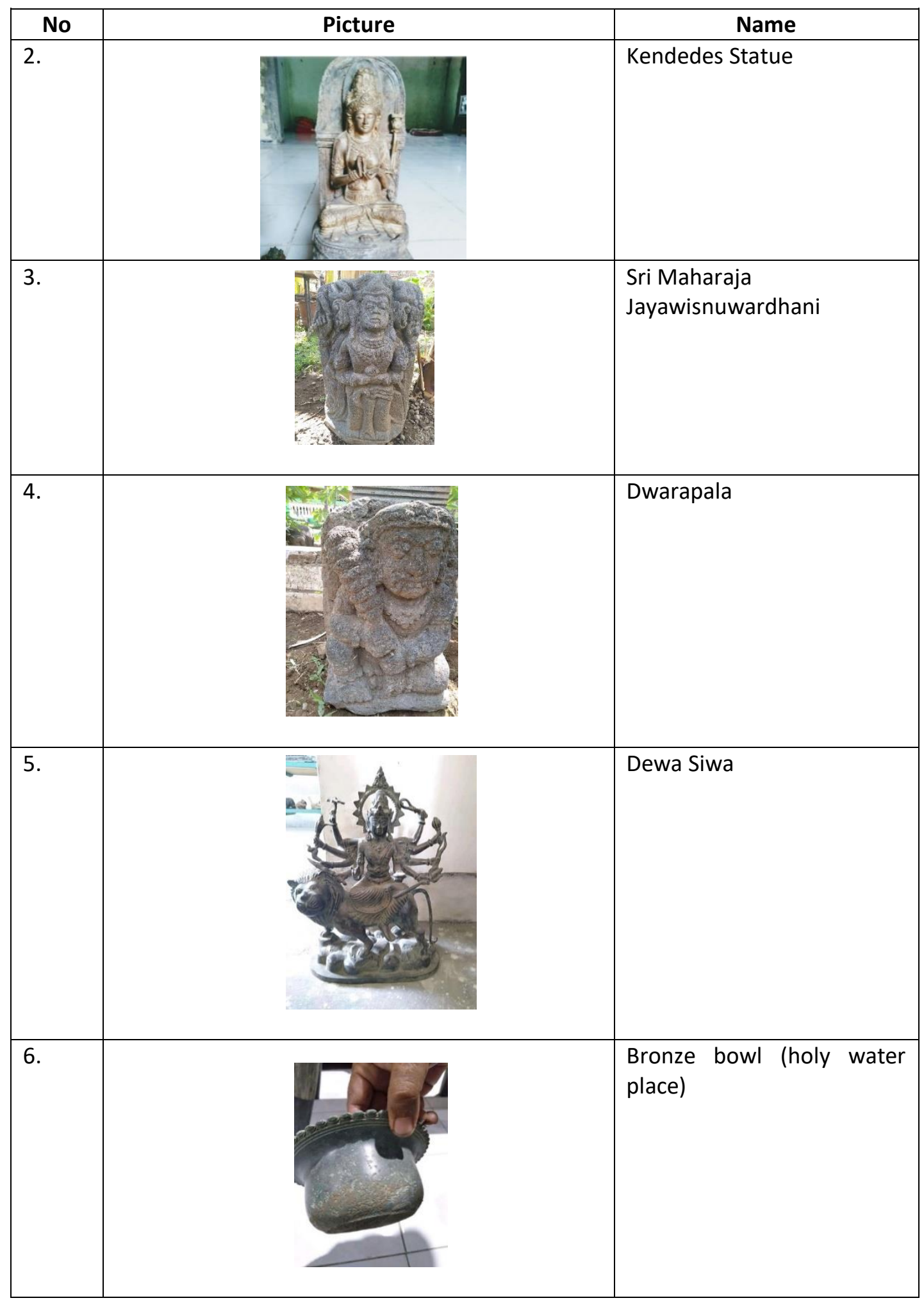

The results of this craft in HR ArtShop can be used as a learning resource for students, especially to learn the historical heritage of the Majapahit kingdom and 
students can also explain the connection between spaces to make an impact in developing the economy, especially in Bejinong Trowulan Mojokerto Village.

\section{B. Learning Local Wisdom through Majapahitan Statue}

Rahyono (2009) suggested that local wisdom is human intelligence possessed by certain ethnic groups obtained through public observation. It means that local wisdom is the result of certain communities through experience and not necessarily experienced by other communities. The majapahitan statue that has been spelled out on the other side, becomes the material for teachers to design learning based on local wisdom. The benefits of learning by using the majapahitan statue can provide contextual experience and learning. This is in line with the opinion of Pannen and Sardiyo (2005) that a learning environment tailored to the cultural background of students will make learning more active and enjoyable.

Related with this study, Pornpirnon (2014) tougth that one of Success factors in the local wisdom application of sustainable school emphasis in the role of teacher is tehacher study community and information to the community both observations and query the locals. The local knowledge as well as the students around the issues of the community defined in the curriculum to lead to learnig.

In this study discussing statue, which has the following definition, the statue is a fine art in the form of three dimensions. Seytiaji and Hanif (2018:63) explain that the process of making statues is usually with engravers made of stone or wood and has long been known by our ancestors before Hindu and Buddhist religions entered Indonesia. In classical times, statues were used to decorate places of worship. In this modern era, the statue is used to decorate buildings or monuments. This is following the results of research that has been done for the majapahitan statue, related to its material and function. The materials used to make Majapahitan statues are stone and brass. For the function of this statue is as decoration and there is also one as a means of worship. In the process of making majapahitan statue can be analyzed with posistive values in life that can be conveyed to students. The following is described haisl analisi on the values found in statues that can be taught to elementary school students.

Table 3. Values contained in Majapahitan Statue for learning materials

\begin{tabular}{|l|l|l|}
\hline No & \multicolumn{1}{|c|}{ Value } & \multicolumn{1}{c|}{ Description } \\
\hline 1 & Cooperation & $\begin{array}{l}\text { The value can be because the process of making statues } \\
\text { can be done in groups so that it requires cooperation } \\
\text { between members. }\end{array}$ \\
\hline 2 & Creative & $\begin{array}{l}\text { In the process of making statues students must creatively } \\
\text { utilize materials and tools and motifs created because } \\
\text { they can make modifications in the making of statues. }\end{array}$ \\
\hline
\end{tabular}


51 Learning Local Wisdom in Elementary School Through Majapahitan Statue

Putri Rachmadyanti, Aristiya Nuraini, Wiryanto

\begin{tabular}{|l|l|l|}
\hline 3 & History & $\begin{array}{l}\text { By knowing the craft of majapahitan statues students will } \\
\text { increase their insight in the field of history, especially the } \\
\text { Majapahit kingdom. }\end{array}$ \\
\hline 4 & Economic & $\begin{array}{l}\text { By knowing that statue can help the economy of the } \\
\text { community, students can understand the benefits of local } \\
\text { wisdom for the community, one of them in the field of } \\
\text { economics. }\end{array}$ \\
\hline 5 & Discipline & $\begin{array}{l}\text { In the process of making a statue requires a disciplined } \\
\text { nature in order for the resulting statue to be maximal. }\end{array}$ \\
\hline
\end{tabular}

Based on the table, it can be known that through the media of the majapahitan statue, implied values of life such as cooperation, creativity, history, economy, and discipline. This is certainly in line with the skills that must be learned in the 21st Century, namely social skills. Zubaidah (2016: 5) has good social skills can help students to make a good decision. Good social skills in children and adolescents can affect their academic performance, social and family skills, and involvement in extracurricular outcomes. Related with Albantani (2018) explain that local wisdom possessed by Indoensia could feasibly build he nation character as well as the identity of Indoensia.

Furthermore, the description of these values can be realized in the writing of the Learning Plan (RPP). The plan refers to the current curriculum of 2013 with a scientific thematic approach. Utari (2016:40) conveys that meaningful and joyful thematic learning can be realized by associating learning materials in the nearest world of students. To contextualize thematic learning can be done through planting local values, local wisdom where students are located. This is beneficial for maintaining and preserving local culture while helping students face growing challenges. Today's education hopes to achieve meaningful learning with principled think globally, act locally.

According to the value in tables about Statue Majapahitan, we knows that in the processing making the statue have postitive value or character for student, such as discipline cooperative, creative. The values can develop the student to be a good citizenship. Yulininingsih (2019) explain that Tradition has the values of mutual cooperation, unity and integrity, deliberation, social control, and local wisdom. The following is an example of learning plan based on the Majapahit Statue as a learning resource. 


\section{Education Unit}

Class/ semester

Time allocation

Themes/ Subtheme/Learning

Pahlawan
: Elementary School

$:$ IV/ 1

: 1 day

: Theme 5 Pahlawanku/ Subthema 1/Perjuangan Para

\section{Learner Objectives}

Indonesia Language

1. By reading the text reading "Sejarah Kerajaan Majapahit" students can write new knowledge that has been found from the nonfiction reading text "Majapahit Kingdom History" neatly.

\section{Civic Education}

1. By conducting a discussion about religious diversity in Majapahit kingdom students can analyze the values of Pancasila please first by associating religious diversity in Majapahit kingdom and surrounding communities.

Social Studies

1. By doing a virtual field trip in one of the craftsmen majapahitan statues students can know the results of the Majapahit kingdom carefully.

2. By doing a virtual field trip in one of the craftsmen majapahitan statue students can identify the Activity results of Majapahit kingdom properly.

1. Early:

a. Greetings, prayer, and absent

b. The teacher performed apperception by showing pictures and statues of Kendedes and then doing Q\&A about the Majapahit kingdom.

2. Core

a. Students are allowed to ask questions that the Majapahit kingdom wants to know ( Asking )

b. Students are asking to read the text of Majapahit royal history and discover new knowledge obtained from the text ( observing)

c. Students write new knowledge about Majapahit kingdom from the reading text on the sheet that has been provided ( try)

d. Students are giving the task of retelling Majapahit kingdom based on their understanding and are presented with the value of religious diversity (communicating)

e. Students are guided to do a virtual field trip by looking at the process of sculpting statues in Bejijong Trowulan village and then students identify the remains of Majapahit Kingdom (observing and reasoning)

f. Students and teachers discuss the values in Majapahitan Statue (try)

g. Students make a report on Majapahit royal relics in the form of statues and then presented (communicated)

h. Teachers provide strengthening lesson

3. Final

a. Reflection, Evaluation, Follow-up

\section{Asessmen}

a. Cognitive Assessment (Knowledge of The History and Legacy of Majapahit Kingdom)

b. Affective assessment ( student attitude when responding to religious diversity)

c. Psychomotor assessment ( Product report) 
53 Learning Local Wisdom in Elementary School Through Majapahitan Statue

Putri Rachmadyanti, Aristiya Nuraini, Wiryanto

\section{Conclution}

Local wisdom-based learning is important in elementary schools so that students understand the environment and local history and civilization, especially in this study of the Majapahit kingdom. Majapahitan statue has values that can be developed in elementary school learning. Students can develop cognitively, affectively, and psychomotor. The learning done by teachers will certainly be wiser and develop when the community and all stakeholders help instill local wisdom values. In addition to preserving culture, local eucharist learning also seeks to identify regional potential to make students more proud of the Indonesian nation.

\section{References}

Albatani, A.M., \& Madkur, A. 2018. Think Globally, Act Locally: The Strategy of Incorporating Local Wisdom in Foreign Language Teaching in Indonesia. International Journal of Applied Linguistics and English Literature, Vol 7, page 1-8

Basri, Hasan. Kemampuan kognitif dalam meningkatkan efektvitas pembelajaran ilmu social bagi siswa sekolah dasar. Jurnal Penelitian Pendidikan

Moleong, Lexy.J. 2014. Metodelogi Penelitian Kualitatif. Bandung: PT. Remaja Rosdakarya.

Prawet Wasi. 1993. National education with local wisdom. "Local Wisdom and Rural Development". Bangkok: Amarin Printing Group.

Puspita, Ari Metalin Ika, dkk. 2019. Peningkatan Kemampuan Menulis Kreatif Siswa Sekolah Dasar melalui Pembelajaran Berbasis Kearifan Lokal. Jurnal Pendas: Jurnal IImiah Pendidikan Dasar Volume IV Nomor 2 Tahun 2019.

Pornpimon, C., Wallapha,.A., \& Prayuth, C. 2014. Strategy challenges the local wisdom applications sustainability in school. Procedia-Social and Behavioural Sciences, $112,626-634$.

Rusman. 2017. Belajar dan pembelajaran. Jakarta: Kencana.

Setyaji, Nanda Cahyo dan Muhammad Hanif. 2018. Kajian Makna Simbolis dari Patung dan Monumen di Kabupaten Ponorogo sebagai Sumber Pembelajaran Sejarah Lokal. Jurnal Agastya Volome 8 Nomor 1 Januari th 2018

Suyono dan Hariyanto. 2015. Belajar dan Pembelajaran Teori dan Konsep Dasar. Bandung: PT. Remaja Rosdakarya.

Utari, Unga, I Nyoman Sudana Degeneg, Sa'dun Akbar. 2016. Pembelajaran Tematik Berbasis Kearifan Lokal Di Sekolah Dasar Dalam Menghadapi Masyarakat Ekonomi Asean (MEA). Jurnal Teori dan Praksis Pembelajaran IPS Vol.1 No.1 April 2016 
Sardiyo dan pannen. 2005. Pembelaaran Berbasis Budaya: Model Inovasi Pembelajaran dan Implementasi Kurikulum Berbasis Kompetensi. Jurnal pendidikan :

Suparno, Paul. 2001. Teori Perkembangan Kognitif Jean Piaget. Yogyakarta : Kanisius.

Rahyono. F.X. (2009). Kearifan Budaya dalam Kata. Jakarta: Wedatama Widyasastra.

Yuliningsih, Y. Saddhono, K. \& Setiawan, B. 2019. Internalizing the Local Wisdom Value of Nyadran Tradition to Students through Audio Visual Media.

Zubaidah, Siti. 2016. Keterampilan Abad ke-21: Ketrampilan yang diajarkan melalui Pembelajaran. Disampaikan pada Seminar Nasional Pendidikan dengan tema "Isu- isu Strategis Pembelakaran MIPA Abad 21, tanggal 10 Desember 2016. and conditions of the Creative Commons Attribution ShareAlike (CC BY SA) license (https://creativecommons.org/licenses/by-sa/4.0/). 